\title{
The Use of Rumen Contents as Bio-Activators for Fermentation in Goat Manure Fertilizer Production
}

\author{
Wehandaka Pancapalaga ${ }^{1, *}$, Suyatno Suyatno ${ }^{1}$ and David Sedlacek ${ }^{2}$ \\ ${ }^{1}$ Department of Animal Science, Faculty of Agriculture and Animal Science, \\ University of Muhammadiyah Malang, Jl Raya Tlogomas no 246, Malang 65145, \\ East Java, Indonesia \\ ${ }^{2}$ Department of Life Siences, Faculty of Science, Masaryk University, Zerotinovo namesti 9, \\ Brno 601 77, Czech Republic
}

\begin{abstract}
Slaughterhouse waste cause environmental problems. Rumen content comprise a lot of enzymes of potential bacteria as bio-activators in the process of making goat manure fertilizer. The study aimed to evaluate the quality of goat manure fertilizer added with rumen content. The materials used were goat manure and cattle rumen contents. The research method uses a Completely Randomized Designed (CRD). The percentages of cattle rumen contents treatments i.e. $0 \%, 5 \%, 10 \%$ and $15 \%$. The variables measured were Nitrogen $(\mathrm{N})$, Phosphor $(\mathrm{P})$, Potassium $(\mathrm{K})$, Carbon organic, $\mathrm{C} / \mathrm{N}$ ratio and moisture content. The results showed, the addition of rumen contents had a very significant effect $(p<0.01)$ on $\mathrm{C}$ organic, $\mathrm{P}, \mathrm{N}$, and $\mathrm{C} / \mathrm{N}$, but had no significant $(p>0.05)$ on $\mathrm{K}$ and moisture content. The results showed that the best treatment was addition of $15 \%$ rumen, that had N $1.59 \%, \mathrm{P} 0.15 \%, \mathrm{~K}$ $0.72 \%, \mathrm{C}$ organic $30.60 \%, \mathrm{C} / \mathrm{N} 19.24 \%$, and moisture content $45.86 \%$. This content had fulfilled SNI 19-7030-2004 for goat manure fertilizer. It could be concluded that giving rumen contents could increase N, P, K, C organic and decrease $\mathrm{C} / \mathrm{N}$ and moisture content.
\end{abstract}

Key words: Bio-activator, environment friendly, organic fertilizer, prevent river pollution, utilization slaughterhouse waste

\section{Introduction}

One of the slaughterhouse wastes is the contents of the rumen, in the form of grass that has not been fermented and fully digested by the cattle. Cattle rumen also contains nutrients that are used by microbes as an energy source. The rumen also functions as a bio-activator to accelerate the process of maturation of organic compost [1], because the rumen contents comprised many microorganisms, including bacteria $\left(10^{9} \mathrm{~mL}^{-1}\right.$ to $10^{12} \mathrm{~mL}^{-1}$ rumen fluid), protozoa $\left(10^{5} \mathrm{~mL}^{-1}\right.$ to $10^{6} \mathrm{~mL}^{-1}$ liquid rumen), and a number of fungi [2].

* Corresponding author: pancapalaga1966@gmail.com 
Abundant population of microorganisms living in the rumen is very valuable to organic farms. The rumen contents of ruminants slaughterhouse such as cattle and goats were usually dispose, even though it is rich in nutrients. The waste is actually very potential when used for the process of making liquid and solid organic fertilizer, including as a bioactivator in the process of making goat manure fertilizer.

Organic fertilizer needs ingredient that has optimal initial $\mathrm{C} / \mathrm{N}$ ratio of 10 to 20 , a moisture content of $30 \%$ to $60.5 \%$ and good porosity of the material. Whereas, the rumen contents of cattle only have a $\mathrm{C} / \mathrm{N}$ ratio between 6.44 to 13.71 [3] and the value of the $\mathrm{C} / \mathrm{N}$ ratio of goat manure is generally still above 30 . According to [4], if the $\mathrm{C} / \mathrm{N}$ ratio is too low, the excess nitrogen will be not used by microorganisms, so it cannot be assimilated. Therefore, Nitrogen will be lost through volatility as ammonia or denitrified. On the contrary, the $\mathrm{C} / \mathrm{N}$ ratio too high, the biological activity of microorganisms will be reduced. It takes several cycles of microorganisms to degrade compost, thus it takes a long time for composting and resulting lower quality fertilizer.

Based on the description above, it was necessary to study the quality of goat manure fertilizer with rumen contents addition as a bio-activator for fermentation.

\section{Material and methods}

The fermentation process was conducted for $21 \mathrm{~d}$ in the University of Muhammadiyah Malang (UMM), East Java, Indonesia experimental farm. The material used was manure taken from Etawa Buck (Capra aegagrus hircus). The fresh rumen content were taken from 2 yr old bulls slaughtered in Gadang Malang Slaughterhouse (Rumah Potong Hewan).

The research method used was an experimental method. The experiment was carried out by adding rumen contents to goat manure for fermentation. The design of the experiment used a Completely Randomized Designed (CRD). The treatments were addition of rumen content $(0 \%, 5 \%, 10 \%$ and $15 \%)$ of percentage of goat manure used.

The research variables measured were the content of $\mathrm{N}, \mathrm{P}, \mathrm{K}, \mathrm{C}$ organic, $\mathrm{C} / \mathrm{N}$ ratio, and moisture content. K content was measured by the Spectrophotometry, nitrogen content was measured using the Kjeldahl, and phosphorus content was measured using the Atomic Absorption Spectrophotometric (AAS). The $\mathrm{C} / \mathrm{N}$ ratio was obtained using the calculation of $\mathrm{C} / \mathrm{N} \times 100 \%$.

The collected data was analyzed by one-way variance analysis. If there are differences between treatments, further tests are performed using Duncan's Multiple Range Test (DMRT). SPSS version 19 software was used to facilitate analysis.

Each experiment unit consist of $2 \mathrm{~kg}$ Buck wet manure, $10 \%$ commercial starter solution $\left(\mathrm{v} \mathrm{v}^{-1}\right)$ and $5 \%$ molasses. Then, rumen contents were added according to the treatment $(0 \%, 5 \%, 10 \%$ and $15 \%)\left(\mathrm{v} \mathrm{v}^{-1}\right)$ for composting. The anaerobic composting process was done for $20 \mathrm{~d}$, temperature and organoleptic were checked every $3 \mathrm{~d}$.

\section{Results and discussions}

The analysis result of the quality of goat manure fertilizer combined with rumen contents at various levels are presented in Table 1. 
Table 1. Laboratory analysis of the quality of goat manure fertilizer

\begin{tabular}{|c|l|c|c|c|c|c|}
\hline \multirow{2}{*}{ No } & \multicolumn{2}{|c|}{ Parameter } & \multicolumn{6}{|c|}{ Percentage of rumen contents addition } & SNI 19-7030-2004 \\
\cline { 3 - 7 } & & $0 \%$ & $5 \%$ & $10 \%$ & $15 \%$ & \\
\hline 1. & Total of Nitrogen (\%) & 1.49 & 1.49 & 1.49 & 1.59 & $\geq 0.40$ \\
\hline 2. & Phosphor (\%) & 0.13 & 0.14 & 0.13 & 0.15 & $\geq 0.10$ \\
\hline 3. & Potassium (\%) & 0.62 & 0.63 & 0.69 & 0.72 & $\geq 0.20$ \\
\hline 4. & C organic (\%) & 31.65 & 31.30 & 31.20 & 30.60 & 9.8 to 32 \\
\hline 5. & C/N & 21.2 & 21.0 & 20.9 & 19.24 & 10 to 20 \\
\hline 6. & Moisture content (\%) & 47.7445 & 47.63 & 47.41 & 45.86 & 50 \\
\hline
\end{tabular}

*SNI 19-7030-2004: Indonesian standard for compost and organic manure

Goat manure fertilizer quality parameters with the addition of rumen contents in various levels were illustrated from the $\mathrm{N}, \mathrm{P}, \mathrm{K}, \mathrm{C}$ organic content, $\mathrm{C} / \mathrm{N}$ ratio and moisture content are explained as follows:

\subsection{Total nitrogen content}

Table 1 showed that the $\mathrm{N}$ content of goat feces fertilizer added by $15 \%$ rumen content resulting in highest content than the others. This was presumably because the addition of $15 \%$ rumen contents, the microorganisms in the rumen were able to work more optimally to decompose goat manure. Nitrogen in the rumen or in goat manure used by microorganisms as a food source to form new cells. Microorganisms decomposed proteins and other nitrogenous organic matter, and ammonia release occurred. After the composting process, the microbes died and become a source of $\mathrm{N}$ in goat manure fertilizer. According to [5], the higher the $\mathrm{N}$ content of the composting base material, the easier it is to undergo a decomposition process, and the higher the total $\mathrm{N}$ compost level will be. The increase in nitrogen content in the composting process is also influenced by the activity of microorganisms in the composting.

\subsection{Phosphorus content}

Table 1 stated that the phosphorus content from the goat manure increase along with the addition of rumen contents, with the highest $\mathrm{P}$ content occurred in $15 \%$ rumen content addition. It was expected that by adding rumen contents more, the organic material would also be higher. Therefore, microorganisms would remodel the goat manure and increase of phosphorus availability. According to [6], the phosphorus content was also influenced by the high nitrogen content. The higher the nitrogen, the the higher the P content.

\subsection{Potassium content}

Table 1 showed that the potassium content in goat manure which was added $15 \%$ rumen content was highest than the others. This increased in potassium was due to the addition of $15 \%$ rumen content which had more forage residue. The more forage residu, the higher $\mathrm{K}$ content. Potassium was used by microorganisms for its activity during the fermentation process. According [7] an increase in potassium due to the composting process will release $\mathrm{K}^{+}$ions from cation exchange and decomposition of organic matter dissolved in rumen contents. 


\subsection{C organic content}

The content of $\mathrm{C}$ organic fertilizer can improve soil properties. $\mathrm{C}$ organic functions as a means of photosynthesis in plants and also as a buffer for the supply of nutrients for plants.

Table 1 stated that the $\mathrm{C}$ organic content of goat manure fertilizer which was given a higher level of rumen content contained higher $\mathrm{C}$ organic compared to the others. This could be due to the addition of rumen contents in goat manure that also added the number of decomposing bacteria (bio-activator) to the material so that it could accelerate the $\mathrm{C}$ organic decomposition process. The higher rumen content addition, the higher $\mathrm{C}$ organic in goat manure fertilizer. Moreover [8] stated that the quality of organic matter greatly determines by the speed of decomposition and mineralization of organic matter.

\section{$3.5 \mathrm{C} / \mathrm{N}$ ratio}

The composting process is a process of decomposition of organic matter from a high $\mathrm{C} / \mathrm{N}$ ratio to a low $\mathrm{C} / \mathrm{N}$ ratio (15 to 25 ) with an effort to activate the microbial activity of a remodel or decomposer (bacteria, fungi, and actinomycetes). A $\mathrm{C} / \mathrm{N}$ ratio level is used to assess the maturity of compost produced during the composting process. $\mathrm{C} / \mathrm{N}$ ratio can be used to predict the mineral mineralization rate of organic matter [9].

Table 1 showed that the $\mathrm{C} / \mathrm{N}$ ratio of goat manure fertilizer added by the rumen content $15 \%$ was higher than the others. It was due to differences in the percentage of rumen biogas contents in each treatment affecting the work of bacteria in the degradation process. The less rumen content was added, the less worked the bacteria. The small number of bacteria in the rumen contents made the goat manure fertilizer was not ready to use, while nitrogen was used to form organism cells in the degradation process. According to [8] too high ratio of $\mathrm{C} / \mathrm{N}$ compost resulting $\mathrm{N}$ immobilization, because all inorganic nitrogen available in the soil will be converted into organisms' bodies in organic form. Then, there is competition for nitrogen between host plants and bacteria. When the $\mathrm{C} / \mathrm{N}$ ratio is less than 20 , it means that there has been a release of nitrogen from organic matter due to decomposition into the soil [10].

\subsection{Moisture content}

The resulting moisture content was the lowest by the addition of $15 \%$ rumen content. In composting process, the moisture content would decrease along with the level of compost maturity. According to [6], the efficiency of the composting process will be reduced if the moisture content was too low. Optimal moisture content in composting was $45 \%$ to $55 \%$. If the moisture content exceeds $60 \%$, the volume of air was reduced, odors will be generated due to aerobic conditions and decomposition becomes slow.

\section{Conclusions}

$\mathrm{N}, \mathrm{P}, \mathrm{K}, \mathrm{C}$ organic, $\mathrm{C} / \mathrm{N}$ ratio and moisture content of goat manure fertilizer in this study fulfilled SNI 197030-2004 requirements. The best quality of goat manure fertilizer was occurred from $15 \%$ rumen content addition. 


\section{References}

1. M.P. Bernal, J.A. Alburquerque, R. Moral. Bioresour. Technol.. 100,22: 5444-5453(2009). https://doi.org/10.1016/j.biortech.2008.11.027

2. Suhardjadinata, D. Pangesti, T. Tedjaningsih. Jurnal Agro. 5,1:29-47(2018). [in Bahasa Indonesia]. https://doi.org/10.15575/1675

3. R.A. Wulandari, Y. Trihadiningrum. Proses komposting limbah padat rumah potong hewan dengan metode Aerobik dan AAO (Anaerobik-Anoksik-Oksik). [Composting process of slaughterhouse solid waste by Aerobic and AAO (Anaerobic-Anoxic-Oxy) Methods]. Seminar nasional 2014-Waste management II, (Surabaya, Indonesia 2014). Seminar nasional 2014-Waste management II. [in Bahasa Indonesia]. http://digilib.its.ac.id/ITS-Master-33103150001233/36601

4. N. Kamolmanit, A. Reungsang. J. Water Environ. Technol. 4,1:33-50(2006). https://doi.org/10.2965/jwet.2006.33

5. R. Guo, G. Li, T. Jiang, F. Schuchardt, T. Chen, Y. Zhao, et al. Bioresour. Technol 112:171-178(2012).

http://dx.doi.org/10.1016/j.biortech.2012.02.099

6. S. Uçaroğlu, U. Alkan. J Air Waste Manag Assoc. 66,3:288-295(2016). http://dx.doi.org/10.1080/10962247.2015.1131205

7. X.Z. Yu, F.F. Zhang. Appl. Environ. Biotechnol. 2,1:29-36(2017). http://doi.org/10.26789/AEB.2017.01.004

8. S. Trivedi, O. Chahar, K. Mehta. Journal of Ecology and Environmental Sciences. 6,1:147-153(2015).

http://www.bioinfopublication.org/viewhtml.php?artid=BIA0002501

9. N. Zhu. Bioresour Technol. 98,1:9-13(2007). https://doi.org/10.1016/j.biortech.2005.12.003

10. M. Clarholm, U. Skyllberg, A. Rosling. Soil Biol. Biochem. 84: 168-176(2015). https://doi.org/10.1016/j.soilbio.2015.02.019 